\title{
EFFECTS OF ASCORBIC ACID, DEXAMETHASONE, AND INSULIN ON THE CATECHOLAMINE AND OPIOID PEPTIDE STORES OF CULTURED ADRENAL MEDULLARY CHROMAFFIN CELLS ${ }^{1}$
}

\author{
STEVEN P. WILSON ${ }^{2}$ AND NORMAN KIRSHNER \\ Department of Pharmacology, Duke University Medical Center, Durham, North Carolina 27710 \\ Received January 7, 1983; Revised March 8, 1983; Accepted April 4, 1983
}

\begin{abstract}
Bovine adrenal medullary chromaffin cells cultured in serum-free medium were examined for changes in their catecholamine and opioid peptide stores following exposure to dexamethasone, ascorbic acid, or insulin for 2 to 12 days. Dexamethasone failed to alter cellular catecholamine levels, measured by high performance liquid chromatography with electrochemical detection, or cellular opioid peptide content, measured by an enkephalin radioreceptor assay. Chromaffin cells cultured in medium supplemented with ascorbic acid retained high ascorbate contents for 2 to 3 days, despite the rapid loss of this vitamin from the culture medium (approximately $50 \%$ lost in 2 $\mathrm{hr}$ ). The epinephrine and norepinephrine contents of chromaffin cell cultures supplemented with ascorbate for 7 days were increased approximately $10 \%$ compared to cultures without added ascorbic acid; ascorbate had no effect on chromaffin cell opioid peptide levels. Addition of insulin to chromaffin cell cultures produced a doubling of cellular protein and opioid peptide levels by 6 days and produced a concentration-dependent increase in the dopamine and norepinephrine contents of the cells with only a slight elevation in cell epinephrine.

Chromaffin cells were also tested for the ability to resynthesize their catecholamine and opioid peptide stores following depletion as the result of secretion evoked by acetylcholine or nicotine. The cellular stores of norepinephrine and dopamine were resynthesized within 3 days following secretagogue-evoked depletion. Epinephrine stores were incompletely replenished with only $20 \%$ of the epinephrine lost via secretion recovered in 7 days. Opioid peptide levels were maximally recovered (50\% of the amount secreted) within 1 day. Addition of ascorbic acid, dexamethasone, or insulin to the medium failed to enhance the recovery of catecholamine stores.
\end{abstract}

Chromaffin cells of the adrenal medulla have a common embryological origin with postganglionic sympathetic neurons (Coupland, 1965) and are useful models for studying the molecular mechanisms underlying the functions of peripheral and central catecholaminergic neurons. The recent discovery of large amounts of opioid peptides (OPs) in the adrenal medulla (Schultzberg et al., 1978; Lewis et al., 1979; Viveros et al., 1979; Yang et al., 1980) further suggests the usefulness of the chromaffin cell as a model for peptidergic neurons. The development of methods for the dissociation and culture of

\footnotetext{
${ }^{1}$ This work was supported by National Institutes of Health Grants AM05427 and NS06233 and by grants from the North Carolina Affiliate of the American Heart Association and the North Carolina United Way. The assistance of John T. Rowland in preparation of the chromaffin cells and of Dorothy L. Kamin in performing the catecholamine analyses is gratefully acknowledged.

${ }^{2}$ To whom correspondence should be addressed.
}

chromaffin cells, most often derived from the adult bovine adrenal medulla, has led to an increased interest in not only the biochemistry but also the biology of these cells.

Dissociated adult bovine chromaffin cells in culture maintain many properties of the chromaffin cell in vivo The cells retain most of their initial catecholamine (CA) content (Waymire et al., 1977; Kilpatrick et al., 1980; Trifaro and Lee, 1980; Muller and Unsicker, 1981; Wilson and Viveros, 1981; Wilson et al., 1981) with the same proportions of epinephrine and norepinephrine as found in the intact gland, although under certain culture conditions a pronounced loss of epinephrine content has been observed (Livett et al., 1978; Unsicker et al., 1980). Chromaffin cells in culture also retain the CA biosynthetic enzymes tyrosine hydroxylase, dopamine $\beta$-hydroxylase, and phenylethanolamine $N$-methyltransferase (Waymire et al., 1977; Kilpatrick et al., 1980; Wilson et al., 1981; Naujoks et al., 1982). Levels of tetrahydro- 
biopterin, a cofactor for tyrosine hydroxylase, and those of its rate-limiting biosynthetic enzyme guanosine triphosphate cyclohydrolase in the culture cells are comparable to those found in vivo (Viveros et al., 1981; M. M. Abou-Donia, S. P. Wilson, C. A. Nichol, and O. H. Viveros, manuscript in preparation). In addition, these cells retain high levels of OPs as well as the ability to synthesize and process enkephalin precursors to Metand Leu-enkephalin (Wilson et al., 1980, 1981; Rossier et al., 1981). Cultured bovine chromaffin cells secrete large quantities of CAs and OPs in response to stimulation of nicotinic cholinergic receptors or in response to other secretagogues (Kilpatrick et al., 1980; Trifaro and Lee, 1980; Livett et al., 1981; Rossier et al., 1981; Wilson et al., 1982) and have been used extensively to study the molecular mechanisms of stimulus-secretion coupling.

Despite the popularity of this culture system, few studies on the optimal conditions for maintaining chromaffin cells in culture have appeared. Wilson and Viveros (1981) have shown that chromaffin cell total CA levels and secretory capacity are maintained in serumfree culture medium. Optimum retention of CA content depends on cell density and the frequency of medium replacement, suggesting that medium "conditioning" is required for chromaffin cell maintenance. Other studies have focused on the regulation of tyrosine hydroxylation in chromaffin cells (Waymire et al., 1977; Wilson et al., 1981; Haycock et al., 1982; Meligeni et al., 1982; M. M. Abou-Donia, S. P. Wilson, C. A. Nichol, and O. H. Viveros, manuscript in preparation), but not on the regulation of total CA stores.

In this report, we describe the effects of serum-free medium supplemented with ascorbate, dexamethasone, or insulin on chromaffin cell epinephrine, norepinephrine, dopamine, and $\mathrm{OP}$ levels. We also describe the ability of cultured chromaffin cells to resynthesize their $\mathrm{CA}$ and $\mathrm{OP}$ stores following loss via evoked secretion.

\section{Materials and Methods}

Materials. Dulbecco's modified Eagle's medium (catalogue no. 430-1600), nutrient mixture F12 (catalogue no. 430-1700), and newborn calf serum were obtained from Grand Island Biological Co. Sodium ascorbate, acetylcholine chloride, HEPES, 5 -fluorodeoxyuridine, and nicotine were obtained from Sigma Chemical Co. Insulin (regular iletin, U-100) was obtained from Eli Lilly and Co. Dexamethasone sodium phosphate (injection, USP) was obtained from Elkins-Sinn. Penicillin G potassium was obtained from Pfizer Laboratories, gentamicin (injection USP) was from Schering Pharmaceuticals, and nystatin was from E. R. Squibb and Sons. Twenty-fourwell tissue culture plates were obtained from Falcon.

Cell culture. Chromaffin cells were isolated from bovine adrenal medullae as previously described (Fenwick ct al., 1978; Kilpatrick et al., 1980; Wilson and Viveros, 1981). The basic medium used for cell culture consisted of $50 \%$ Dulbecco's modified Eagle's medium and 50\% nutrient mixture $\mathrm{F} 12$ with $5 \mathrm{mM}$ HEPES and $28.6 \mathrm{mM} \mathrm{NaHCO}_{3}$ $\left(\mathrm{pH} 7.4\right.$ at $37^{\circ} \mathrm{C}$ and $\left.5 \% \mathrm{CO}_{2}\right)$. Chromaffin cells were seeded in plating medium (the basic medium supplemented with 5 to $10 \%$ newborn calf serum, $20 \mu \mathrm{M} 5$ fluorodeoxyuridine, 100 units of penicillin $/ \mathrm{ml}, 40 \mu \mathrm{g}$ of gentamicin $/ \mathrm{ml}, 50$ units of nystatin $/ \mathrm{ml}$, and $250 \mu \mathrm{M}$ ascorbic acid) at a density of 0.4 to $1.0 \times 10^{6}$ cells $/ 2-\mathrm{cm}^{2}$ well ( 0.5 to $1.0 \mathrm{ml}$ of medium). After approximately 2 days in culture, the plating medium was replaced with $0.5 \mathrm{ml}$ of serum-free maintenance medium (the basic medium supplemented with $10 \mu \mathrm{M} 5$-fluorodeoxyuridine, 100 units of penicillin $/ \mathrm{ml}, 10 \mu \mathrm{g}$ of gentamicin $/ \mathrm{ml}, 50$ units of nystatin $/ \mathrm{ml}$, and $250 \mu \mathrm{M}$ ascorbic acid) as described by Wilson and Viveros (1981). No further medium replacement was performed in the experiments described. Cultures were maintained at $37^{\circ} \mathrm{C}$ in a humidified atmosphere containing $5 \% \mathrm{CO}_{2}$.

Secretion experiments. The maintenance medium of chromaffin cell cultures, 2 to 5 days after plating, was removed with a pipette and pooled according to the treatment the cultures were receiving. Residual medium was removed by aspiration and $500 \mu \mathrm{l}$ of a balanced salts solution $\left(150 \mu \mathrm{M} \mathrm{NaCl}, 5.0 \mathrm{mM} \mathrm{KCl}, 1.0 \mathrm{mM} \mathrm{Na}{ }_{2} \mathrm{HPO}_{4}\right.$, $7.8 \mathrm{~mm}$ glucose, $5 \mathrm{mM}$ HEPES, $1.0 \mathrm{mM} \mathrm{MgSO}_{4}$, and 5.0 $\mathrm{mM} \mathrm{CaCl} 2, \mathrm{pH} 7.4$ ) with or without secretagogue was added to each well. After $30 \mathrm{~min}$ at 22 to $25^{\circ} \mathrm{C}$, aliquots of this solution were removed from selected wells to monitor CA release from the cells. The solution remaining in the wells was removed by aspiration and the cultures were extracted with $1.0 \mathrm{M}$ acetic acid or returned to the culture medium that had been removed before the experiment. Basal secretion, measured by CA analysis of balanced salts solution incubated with unstimulated cells (without secretagogue), averaged $2.2 \pm 1.4 \%$ (mean \pm SD) of the total cell CA content in 25 experiments with 10 separate cell preparations.

Harvesting of cell $C A s, O P s$, and protein. The culture medium of cells to be analyzed for CA and OP levels was removed by aspiration; the cultures were washed once with a cold balanced salts solution $(150 \mathrm{mM} \mathrm{NaCl}, 5.0$ $\mathrm{mM} \mathrm{KCl}, 1.0 \mathrm{mM} \mathrm{Na} \mathrm{HPO}_{4}, 7.8 \mathrm{mM}$ glucose, $5 \mathrm{mM}$ HEPES, $1.0 \mathrm{mM} \mathrm{MgSO}_{4}$, and $1.0 \mathrm{mM} \mathrm{CaCl}_{2}, \mathrm{pH}$ 7.4) and extracted with $250 \mu \mathrm{l}$ of cold $1.0 \mathrm{M}$ acetic acid. After at least $5 \mathrm{~min}$, the acetic acid was removed and stored frozen until analysis. This procedure gives quantitative recovery of cell CA and OP contents (Wilson et al., 1981). When the protein content of cultures was to be measured, cultures were treated similarly as for CA and OP analysis, except that $0.4 \mathrm{M}$ perchloric acid was used in place of acetic acid. The precipitated material (adhered to the plate) was washed once with additional cold perchloric acid and then dissolved at room temperature in 0.6 $\mathrm{M} \mathrm{NaOH}$.

$C A$ and ascorbic acid analysis. Ascorbic acid, norepinephrine, epinephrine, and dopamine levels in acetic acid extracts of chromaffin cells or adrenal medullae were determined by high performance liquid chromatography with electrochemical detection (Bioanalytical Systems LC-153). The extracts were chromatographed on a C-18 reverse phase column (Alltech) eluted isocratically with a mixture of $93 \% 0.15 \mathrm{M}$ chloroacetic acid/1 mM EDTA/ $15 \mathrm{mg}$ of sodium octyl sulfate/liter, $\mathrm{pH} 3.0$, and $7 \%$ methanol. The electrochemical detector utilized a TL-5 glassy carbon electrode set at $0.85 \mathrm{~V}$. Ascorbic acid and CAs were identified by their elution position and quantitated by comparison to appropriate standards.

Other methods. Protein was determined by the method 
of Lowry et al. (1951). OPs were quantitated by displacement of $\left[{ }^{125} \mathrm{I}-\mathrm{D}-\mathrm{Ala}^{2}\right.$, D-Leu $\left.{ }^{5}\right]$ enkephalin from rat brain receptors (Chang and Cuatrecasas, 1979) as modified by Wilson et al. (1981). In some experiments, porcine brain was used as a source of membranes and assays were performed in the presence of $1 \mathrm{mM} \mathrm{MnCl}_{2}$ and $10 \mu \mathrm{M}$ puromycin. Leu-enkephalin was used as the standard; all results are presented as Leu-enkephalin equivalents. Opiate activity in opiate receptor-inactive peptides containing enkephalin sequences (PCES) was measured by the same radioreceptor assay following digestion with trypsin and carboxypeptides B (Wilson et al., 1982). Opiate activity found in excess of that present in samples treated identically but without enzymes is reported as PCES.

Presentation of data. All data are presented as the mean \pm SEM of determinations on triplicate cultures from single experiments, except as noted in legends to figures and tables. In all cases at least one additional experiment, usually on a separate cell preparation, confirmed the results presented.

\section{Results}

In order to understand how various agents affect the $\mathrm{CA}$ and OP stores of chromaffin cells in culture, we first characterized the ascorbic acid, $\mathrm{CA}$, and $\mathrm{OP}$ levels in freshly prepared cells (Table I). As previously reported (Kilpatrick et al., 1980; Trifaro and Lee, 1980; Wilson and Viveros, 1981), chromaffin cells prepared by enzymatic digestion and density gradient centrifugation contained large amounts of CAs in the same proportion as found in homogenates of the adrenal medulla. Ascorbic acid levels are somewhat reduced in the dissociated cells $(\mathrm{CA}$ :ascorbic acid ratio $=22$ ) compared to adrenal medullary homogenates (ratio $=12$ ), suggesting preferential losses of ascorbate during the cell preparation procedure. CAs may also be lost during cell isolation because the $\mathrm{CA}$-to-OP ratio is somewhat lower in the cells than in homogenates. The possibility that this increased $O P$ relative to CA could reflect increased processing of opiate receptor-inactive $\mathrm{OP}$ precursors to $\mathrm{OP}$ is unlikely because digestion of neutralized extracts with trypsin and carboxypeptidase B before assaying for opiate activity showed similar ratios of PCES to OP in adrenal medullary homogenates $(1.8 \pm 0.2$, mean $\pm \mathrm{SEM}, n=4)$ and in freshly prepared chromaffin cells $(2.0 \pm 0.3, n=5)$.

In four cell preparations, losses of CA upon plating (comparing freshly isolated cells to cells after 2 days in culture) ranged from 35 to $44 \%$ with a preferential loss of norepinephrine (average 53\%) in comparison to epinephrine (average $36 \%$ ). Losses of OP upon plating were somewhat less ( 15 to $35 \%$ ), suggesting that at least part of the CA loss observed is the result of leakage from the cells and not only from cell death or failure to attach to the substratum.

\section{Effects of ascorbic acid, dexamethasone, and insulin}

Ascorbic acid. Omission of ascorbic acid from the medium of chromaffin cell cultures results in reduction of cellular ascorbate to very low levels by 7 days in culture (Table II). Addition of fresh ascorbate to the medium at the time of plating and again when the medium was replaced at 3 days maintained significant levels of cellular ascorbic acid, but the CA-to-ascorbic acid ratio was 30 , somewhat lower than that found in freshly prepared cells (see above). Cultures to which ascorbic acid was added (Table II) exhibited a small but significant elevation in both norepinephrine $(P<0.02)$ and epinephrine $(P<0.005)$ contents. Analysis of ascorbic acid levels in maintenance medium alone incubated at $37^{\circ} \mathrm{C}$ and $5 \%$ $\mathrm{CO}_{2}$ indicated that $50 \%$ of the initial ascorbate was destroyed by approximately $2 \mathrm{hr}$ and that less than $0.05 \%$ remained after $23 \mathrm{hr}$. However, chromaffin cells maintained in medium to which ascorbic acid had been added lost cellular ascorbic acid by an apparent first-order

TABLE I

Ascarbic acid, catecholamine, and opioid peptide contents of the bovine adrenal medulla and freshly prepared chromaffin cells

Adrenal medullae were dissected free of cortical tissue and homogenized in 4 vol of acetic acid/gm of tissue (final concentration was $1.0 \mathrm{M}$ ). Three glands were analyzed for ascorbic acid content; the same three glands plus a pooled homogenate of two additional glands were analyzed for catecholamines and opioid peptides. Chromaffin cells were prepared by the standard method (see "Materials and Methods") or by an alternative procedure using Renografin as the density gradient medium (experiments IIIb and IVb). Freshly isolated cells were extracted in 1.0 $M$ acetic acid. Insoluble material was removed by centrifugation. Analyses were performed on duplicate (experiments III, IV, and V), triplicate (experiments I and VI), or quadruplicate (experiment II) aliquots of cells. Ascorbic acid was always analyzed within 3 days of sample preparation. Average values are given as mean \pm SEM.

\begin{tabular}{|c|c|c|c|c|c|c|c|c|}
\hline Source & $\begin{array}{l}\text { Exp. } \\
\text { No. }\end{array}$ & Ascorbate & $\mathrm{NE}^{a}$ & $\mathbf{E}$ & DA & $\begin{array}{l}\% \mathrm{CA} \\
\text { as E }\end{array}$ & $\begin{array}{c}\text { Opioid } \\
\text { Peptides }\end{array}$ & $\frac{\mathrm{CA}}{\mathrm{OP}}$ \\
\hline & \multicolumn{5}{|c|}{$\mu \mathrm{mol} / \mathrm{gm}$ of tissue } & & nmol/gm & $\times 10^{-3}$ \\
\hline \multirow[t]{7}{*}{ Chromaffin cells } & $\mathrm{I}$ & 5.4 & 41.2 & 82.8 & 0.4 & 66.6 & 40.6 & 3.1 \\
\hline & II & 6.6 & 25.4 & 58.2 & 1.3 & 68.5 & 24.8 & 3.4 \\
\hline & IVa & ND & 28.9 & 97.4 & 2.0 & 76.1 & 61.4 & 2.1 \\
\hline & $\mathrm{IVb}$ & ND & 51.2 & 121.9 & 2.7 & 69.3 & 70.8 & 2.5 \\
\hline & $\mathrm{V}$ & 6.9 & 32.0 & 97.1 & ND & & ND & \\
\hline & VI & 6.0 & 26.9 & 62.4 & 0.6 & 69.5 & ND & \\
\hline & Avg. & $5.5 \pm 0.5$ & $34 \pm 3$ & $81 \pm 8$ & $1.4 \pm 0.3$ & $69 \pm 2$ & $48 \pm 7$ & $2.5 \pm 0.2$ \\
\hline
\end{tabular}

${ }^{a} \mathrm{NE}$, norepinephrine; E, epinephrine; DA, dopamine; CA, total catecholamines; OP, opioid peptides; ND, not determined. 
process with $50 \%$ of the loss occurring in 2.2 days (not shown). Addition of insulin or dexamethasone to the medium did not affect the rate of loss of cellular ascorbate. After 1 day in medium containing ascorbate, cellular ascorbate levels of up to $11 \mathrm{nmol} / 10^{6}$ cells were observed, often exceeding those present in freshly prepared cells (Table I). These results suggest that chromaffin cells possess a mechanism for concentrating ascorbic acid, in keeping with the discovery of a high affinity uptake system for this vitamin in these cells (Daniels et al., 1982; Dean et al., 1982). At a time when the culture medium contains less than $0.06 \mathrm{nmol}$ of ascorbic acid ( 1 day after addition of $250 \mu \mathrm{M}$ ascorbate to cultures in $0.5 \mathrm{ml}$ of medium) chromaffin cells can contain at least $3 \mathrm{nmol}$ of ascorbate $/ 5 \times 10^{5}$ cells. Because the intracellular water space of chromaffin cells is approximately $2 \mu \mathrm{l} / 10^{6}$ cells (M. M. Abou-Donia, S. P. Wilson, C. H. Nichol, and $\mathrm{O}$. H. Viveros, manuscript in preparation), these results suggest that the cells were able to maintain an ascorbate concentration gradient of

TABLE II

Effect of dexamethasone, insulin, and ascorbic acid on chromaffin cell catecholamine and ascorbic acid contents

Chromaffin cells, 400,000 per well, were seeded in plating medium with $250 \mu \mathrm{M}$ ascorbic acid (Asc) and $20 \mu \mathrm{M}$ dexamethasone (Dex) or $0.87 \mu \mathrm{M}$ insulin (Ins) as indicated. After 3 days in culture the serumcontaining medium was removed and replaced with maintenance medium and the additions noted in the table. The cultures were harvested and analyzed after 4 additional days. Bovine serum albumin $(1 \mathrm{mg} / \mathrm{ml})$ was added to culture medium containing dexamethasone or ascorbate, but not with insulin; the presence of albumin was without effect on chromaffin cell catecholamine or ascorbic acid contents.

\begin{tabular}{lcccc}
\hline $\begin{array}{c}\text { Addition to } \\
\text { Medium }\end{array}$ & Ascorbate & $\begin{array}{c}\text { Norep- } \\
\text { ineph- } \\
\text { rine }\end{array}$ & Epinephrine & Dopamine \\
\hline \multicolumn{4}{c}{ nmol/culture } \\
None & $<0.05$ & $6.26 \pm 0.13$ & $14.0 \pm 0.2$ & $0.39 \pm 0.01$ \\
Asc & $0.75 \pm 0.05$ & $6.90 \pm 0.09^{a}$ & $15.6 \pm 0.1^{b}$ & $0.34 \pm 0.01^{c}$ \\
Dex & $<0.05$ & $6.76 \pm 0.22$ & $14.8 \pm 0.4$ & $0.40 \pm 0.01$ \\
Asc + Dex & $0.48 \pm 0.06$ & $6.95 \pm 0.04^{d}$ & $15.7 \pm 0.3^{a}$ & $0.38 \pm 0.01$ \\
Ins & $<0.05 \quad$ & $8.99 \pm 0.28^{c}$ & $15.0 \pm 0.2^{c}$ & $0.85 \pm 0.07^{b}$ \\
Ins + Asc & $2.42 \pm 0.24$ & $8.97 \pm 0.21^{e}$ & $16.0 \pm 0.3^{b . f}$ & $0.77 \pm 0.04^{d}$ \\
\hline & ${ }^{a} p<0.02$ compared to none. \\
${ }^{b} p<0.005$ compared to none. \\
${ }^{c} p<0.025$ compared to none. \\
${ }^{d} p<0.01$ compared to none. \\
${ }^{e} p<0.001$ compared to none. \\
${ }^{f} p<0.05$ compared to insulin alone.
\end{tabular}

at least 25,000-fold if one assumes that cellular ascorbic acid is uniformly distributed in the intracellular water space.

'The rate of ascorbate loss from cultured chromafin cells suggests that replenishment of ascorbate in the culture medium, at a concentration of $250 \mu \mathrm{M}$, is not required more than once every 2 to 3 days to retain high levels of cellular ascorbic acid. Indeed, addition of 200 $\mu \mathrm{M}$ ascorbic acid to cell cultures followed by a 4-day period with no further addition produced an elevation of total cell CAs identical to that when $200 \mu \mathrm{M}$ ascorbate was added to the cultures daily (not shown). Frequent addition of $500 \mu \mathrm{M}$ ascorbic acid suppressed the elevation in total cell CAs observed at lower ascorbate concentrations. All subsequent experiments were performed with addition of $250 \mu \mathrm{M}$ ascorbic acid to the media, except as noted. Ascorbic acid supplementation failed to alter the levels of chromaffin cell OPs.

Dexamethasone. In agreement with earlier studies on the total CA content of chromaffin cells (Wilson and Viveros, 1981), dexamethasone failed to alter cellular CAs significantly (Table II). Dexamethasone addition to the cultures did not affect the responses of chromaffin cells to ascorbic acid or insulin supplementation nor did it alter cell OP levels (data not shown).

Insulin. Addition of $0.87 \mu \mathrm{M}$ insulin to chromaffin cell cultures produced substantial increases in both cellular norepinephrine and dopamine levels with a smaller effect on epinephrine levels after 7 days in culture (Table II). Time course studies revealed that although dopamine increased slowly in cultures without insulin, insulin addition increased the rate of dopamine accumulation such that levels of this amine were significantly elevated by 2 days in culture (Table III). Dopamine levels in insulintreated cells continued to rise over 12 days of culture, but the extent of the insulin-mediated increase varied widely from experiment to experiment. The increases in cellular norepinephrine, and the smaller increases in epinephrine, observed with insulin addition required at least 6 days to become apparent, and their levels continued to increase over 12 days in culture. No increases in chromaffin cell epinephrine and norepinephrine levels were observed without insulin treatment. Insulin also increased the level of ascorbate in chromaffin cells (Table II), apparently by increasing the initial uptake of ascorbate, because the rate of loss was identical in untreated and insulin-treated cultures (not shown).

TABLE III

Effect of insulin on the protein, catecholamine, and opioid peptide contents of chromaffin cell cultures All values are given as the mean \pm SEM for triplicate cultures $\left(5 \times 10^{5}\right.$ cells plated). Insulin, when present, was at a concentration of $1.0 \mu \mathrm{M}$.

\begin{tabular}{|c|c|c|c|c|c|c|c|c|}
\hline $\begin{array}{l}\text { Days in } \\
\text { Culture }\end{array}$ & $\begin{array}{l}\text { Insulin } \\
\text { Present }\end{array}$ & Protein & $\mathrm{NE}^{a}$ & $\mathrm{E}$ & DA & $\mathrm{OP}$ & PCES & $\frac{\mathrm{CA}}{\overline{\mathrm{OP}}}$ \\
\hline 2 & $\begin{array}{l}- \\
+\end{array}$ & $\begin{array}{l}42.4 \pm 1.5 \\
64.1 \pm 0.8^{a}\end{array}$ & $\begin{array}{l}3.5 \pm 0.1 \\
3.6 \pm 0.1\end{array}$ & $\begin{array}{l}12.0 \pm 0.4 \\
12.7 \pm 0.2\end{array}$ & $\begin{array}{l}0.26 \pm 0.01 \\
0.35 \pm 0.003^{b}\end{array}$ & $\begin{array}{l}5.7 \pm 0.1 \\
6.4 \pm 0.2^{c}\end{array}$ & $\begin{array}{l}18.0 \pm 1.6 \\
23.8 \pm 0.4^{\mathrm{c}}\end{array}$ & $\begin{array}{l}2.8 \\
2.6\end{array}$ \\
\hline 6 & $\begin{array}{l}- \\
+\end{array}$ & $\begin{array}{l}48.0 \pm 0.9 \\
90.0 \pm 0.6^{b}\end{array}$ & $\begin{array}{l}3.9 \pm 0.2 \\
5.5 \pm 0.1^{b}\end{array}$ & $\begin{array}{l}11.6 \pm 0.6 \\
13.8 \pm 0.3^{c}\end{array}$ & $\begin{array}{l}0.26 \pm 0.02 \\
0.99 \pm 0.10^{b}\end{array}$ & $\begin{array}{c}5.6 \pm 0.2 \\
13.3 \pm 0.3^{b}\end{array}$ & $\begin{array}{l}13.0 \pm 0.7 \\
42.0 \pm 1.2^{b}\end{array}$ & $\begin{array}{l}2.8 \\
1.5\end{array}$ \\
\hline
\end{tabular}

${ }^{a} \mathrm{NE}$, norepinephrine; E, epinephrine; DA, dopamine; OP, opioid peptides; CA, total catecholamines.

${ }^{b} p<0.005$, compared to cultures without insulin.

${ }^{c} p<0.05$, compared to cultures without insulin. 
Chromaffin cell cultures treated with insulin for 6 days also contained elevated amounts of $\mathrm{OPs}$ and protein (Table III). Incubation of the cells with $\left[{ }^{3} \mathrm{H}\right]$ leucine showed that insulin treatment increased the rate of protein synthesis after only $6 \mathrm{hr}$ of treatment (not shown). The increase in total protein of the cultures precedes the increase in OP levels, but by 6 days the extent of the insulin-induced OP increase is greater than the percentage increase in cell protein (Table III). No further insulin-induced increases in cell protein or OP content were observed after 6 days in culture. Levels of PCES were increased in proportion to OP levels by insulin treatment, indicating that this insulin-mediated increase in cellular OPs does not result solely from increased processing of PCES to OP.

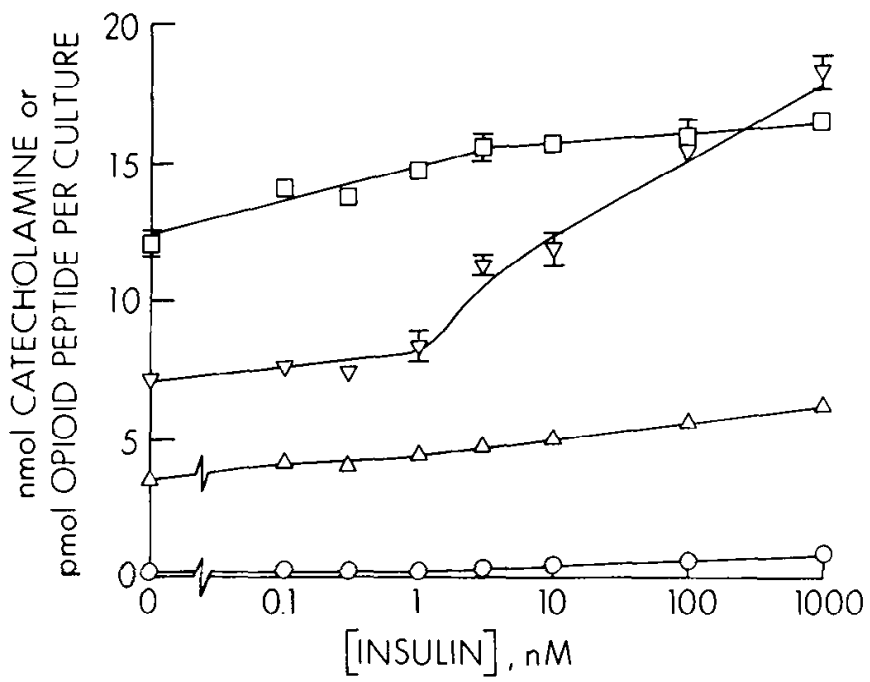

Figure 1. Dependence of chromaffin cell catecholamine and opioid peptide contents on insulin concentration. Chromaffin cells, $5 \times 10^{5}$ per well, were seeded in plating medium and switched to maintenance medium 2 days later. The indicated concentrations of insulin were present throughout the 7 days of culture. Cultures were harvested and analyzed for dopamine $(O)$, norepinephrine $(\triangle)$, epinephrine $(\square)$, and opioid peptide $(\nabla)$ contents. Error bars represent the SEM when this value is larger than the symbol used.
The effect of varying the concentration of insulin in the culture medium was also explored (Fig. 1). Addition of insulin concentrations of up to $1 \mathrm{nM}$ increased chromaffin cell CA and OP contents approximately $20 \%$ without changing their relative proportions. Concentrations of insulin from 1 to $1000 \mathrm{nM}$ produced only a moderate, gradual increase in epinephrine, norepinephrine, and dopamine levels but caused a dramatic increase in OP levels.

Addition of ascorbic acid, dexamethasone, or insulin to the culture medium had no effects on the light microscopic appearance of the chromaffin cells.

\section{Recovery of $C A$ and $O P$ stores following evoked secretion}

Chromaffin cells exposed to $20 \mu \mathrm{M}$ nicotine, in the presence of $5 \mathrm{mM}$ calcium, for $30 \mathrm{~min}$ at 22 to $25^{\circ} \mathrm{C}$ lost approximately $40 \%$ of their CA, OP, and PCES contents in comparison to cells not exposed to nicotine (Table IV), as reported previously (Wilson et al., 1982). The secretory response of chromaffin cells was similar whether nicotine (10 to $20 \mu \mathrm{M}$ ) or acetylcholine $(50 \mu \mathrm{M}$ with $10 \mu \mathrm{M}$ eserine) was used as the secretagogue. The ascorbic acid content of the chromaffin cells was reduced by exposure of the cells to nicotine, although to a much smaller extent than that of the CAs (not shown). In 10 separate experiments cellular ascorbic acid release was $48 \pm 4 \%$ of total CA release when the release of each substance was calculated as a percentage of cell content. These results suggest that as much as half of chromaffin cell ascorbic acid may be stored in chromaffin vesicles, although release from other subcellular compartments (Schneider, 1968) has not been ruled out.

Chromaffin cell cultures exposed to nicotine or acetycholine for $30 \mathrm{~min}$ and then returned to culture medium for an additional 1 to 7 days recovered their norepinephrine and dopamine levels to those of unstimulated controls within 3 days (Fig. 2 and Table IV). However, chromaffin cells usually recovered little of the epinephrine lost by secretion. When recovery of cell epinephrine content was observed, it occurred over the same 3-day time course as norepinephrine and dopamine recovery. Recovery of chromaffin cell OP levels ranged from 35 to $95 \%$ of the secretagogue-induced loss in

TABLE IV

Recovery of chromaffin cell catecholamine and opioid peptide stores following nicotine-evoked secretion

Chromaffin cells, $5 \times 10^{5}$ well, were seeded in plating medium and changed to maintenance medium after 2 days (sec "Materials and Methods"). After $5 \mathrm{hr}$ in maintenance medium, the cells were exposed to balanced salts medium containing $5 \mathrm{mM}$ calcium with or without $20 \mu \mathrm{M}$ nicotine. After $30 \mathrm{~min}$ at room temperature, the media were removed and either $(a)$ the cells were extracted with $1.0 \mathrm{M}$ acetic acid $(0 \mathrm{~min})$ or $(b)$ the original maintenance medium was replaced and culture continued for 3-days before extraction with acetic acid.

\begin{tabular}{|c|c|c|c|c|c|c|}
\hline $\begin{array}{l}\text { Time after } \\
\text { Stimulation }\end{array}$ & $\begin{array}{l}\text { Nicotine } \\
\text { Present }\end{array}$ & Norepinephrine & Epinephrine & Dopamine & opa & PCES \\
\hline \multirow{4}{*}{$0 \min$} & & & nmol/culture & & & \\
\hline & - & $6.18 \pm 0.08$ & $27.3 \pm 0.3$ & $0.76 \pm 0.02$ & $12.9 \pm 0.8$ & $35.9 \pm 1.7$ \\
\hline & + & $3.20 \pm 0.02$ & $16.5 \pm 0.1$ & $0.49 \pm 0.00$ & $7.2 \pm 0.3$ & $22.2 \pm 2.5$ \\
\hline & $\begin{array}{r}\Delta \\
\% \text { loss }\end{array}$ & $\begin{array}{l}2.98 \\
48\end{array}$ & $\begin{array}{l}10.8 \\
40\end{array}$ & $\begin{array}{l}0.27 \\
36\end{array}$ & $\begin{array}{l}5.7 \\
44\end{array}$ & $\begin{array}{l}13.7 \\
38\end{array}$ \\
\hline \multirow[t]{4}{*}{3 days } & - & $6.03 \pm 0.04$ & $25.1 \pm 0.2$ & $0.87 \pm 0.02$ & $12.9 \pm 0.9$ & $33.4 \pm 3.0$ \\
\hline & + & $5.97 \pm 0.10$ & $14.4 \pm 0.2$ & $1.23 \pm 0.04$ & $12.6 \pm 0.4$ & $39.4 \pm 0.5$ \\
\hline & $\Delta$ & 0.06 & 10.7 & -0.36 & 0.3 & -5.0 \\
\hline & $\%$ loss & 1.0 & 42.6 & -41 & 2 & -18 \\
\hline
\end{tabular}

${ }^{a} \mathrm{OP}$, opioid peptides; PCES, peptides containing enkephalin sequences. 

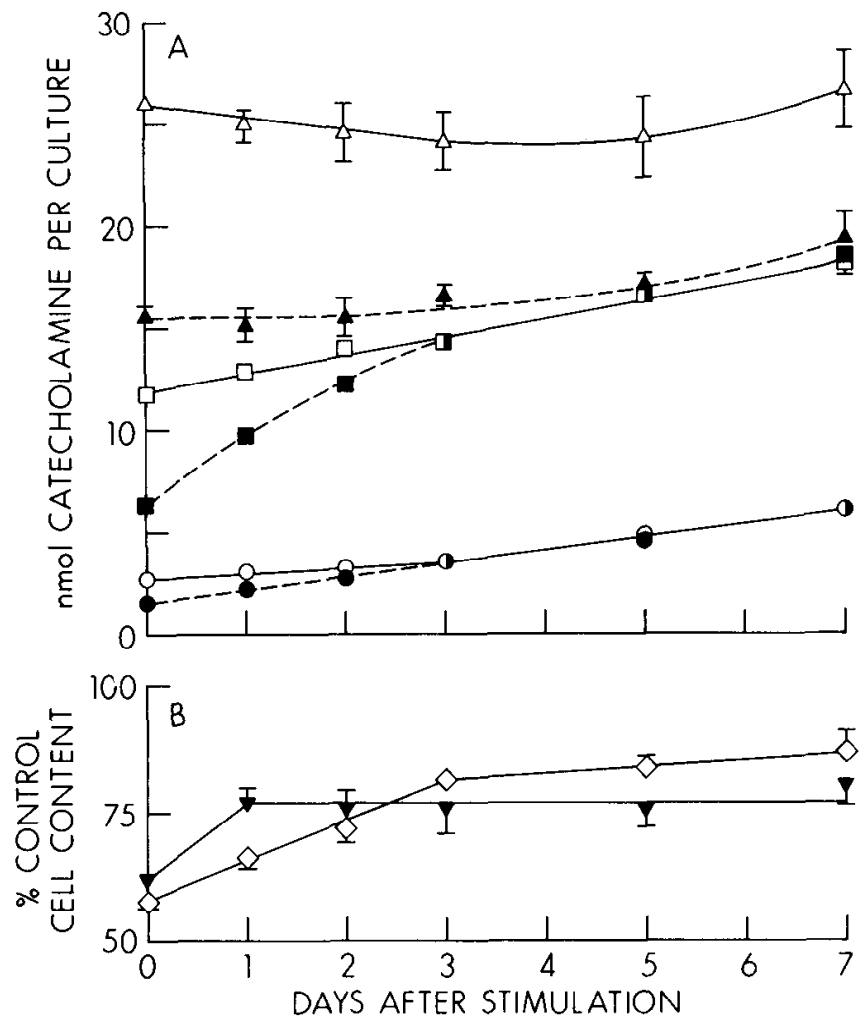

Figure 2. Time course of the recovery of catecholamine and opioid peptide contents of chromaffin cells stimulated with acetylcholine. Chromaffin cells, $4 \times 10^{5}$ per well, were seeded in plating medium containing $1.5 \mu \mathrm{M}$ insulin and switched to insulin-containing maintenance medium after 4 days. After one additional day, cultures were exposed to balanced salts solution containing $10 \mu \mathrm{M}$ eserine (open symbols) or $10 \mu \mathrm{M}$ eserine plus $50 \mu \mathrm{M}$ acetylcholine (solid symbols). Cells were harvested immediately or were returned to their original culture medium and cultured for the times indicated before harvest. The data shown are means of values obtained from quadruplicate cultures; error bars (SEM) are shown where larger than the symbol used. $A$, Analysis of cellular dopamine $(\mathrm{O}, \mathrm{O})$, norepinephrine $(\square, \square)$ and epinephrine $(\Delta, \Delta)$ levels. $B$, Total catecholamine $(\diamond)$ and opioid peptide $(\nabla)$ contents in acetylcholine-stimulated chromaffin cells as a percentage of those found in control cells. Initial total catecholamine and opioid peptide levels in unstimulated cells were $40.5 \pm 0.4 \mathrm{nmol}$ and $42.4 \pm 2.4 \mathrm{pmol} / \mathrm{culture}$, respectively.

various experiments and occurred within 1 day. (Fig. 2, Table IV, and not shown). Recoveries of PCES levels were proportional to those of OPs (Table IV) and also occurred within 1 day.

Effects of insulin, dexamethasone, and ascorbic acid on recovery. The extents of evoked CA and OP secretion were unaffected by treatment of the cells with ascorbic acid $(250 \mu \mathrm{M})$, dexamethasone $(20 \mu \mathrm{M})$, bovine serum albumin $(1 \mathrm{mg} / \mathrm{ml})$, or insulin $(1.5 \mu \mathrm{M})$. Inclusion of insulin in the culture medium containing ascorbate did not alter recoveries of chromaffin cell norepinephrine, epinephrine, or OP following secretion. Dexamethasone inclusion in the culture medium did not consistently alter the recoveries of $\mathrm{CA}$ and $\mathrm{OP}$ stores following secretion, although in certain experiments it slightly increased the recovery of epinephrine or partially suppressed the recovery of $\mathrm{CA}$ and $\mathrm{OP}$ stores. Chromaffin cells cultured in the absence of added ascorbic acid resynthesize their $\mathrm{CA}$ and $\mathrm{OP}$ stores following loss via secretion to the same extent as cells cultured in the presence of ascorbic acid. Cultures $\left(10^{6}\right.$ cells) containing less than $0.1 \mathrm{nmol}$ of cellular ascorbic acid increased their cellular CA content by $9.3 \pm 1.3 \mathrm{nmol}$ within 3 days following evoked secretion. These data suggest that ascorbic acid is not the only source of reducing equivalents in the synthesis of CAs in chromaffin cells.

\section{Discussion}

The present study shows that chromaffin cells in culture are influenced by the addition of ascorbic acid or insulin to the culture medium and that these cells are capable of complete resynthesis of norepinephrine and partial resynthesis of epinephrine, OP, and PCES stores lost during evoked secretion.

Ascorbic acid. Chromaffin cell cultures retained high levels of ascorbic acid if the culture medium was supplemented with this vitamin. Although a portion of this ascorbic acid could be present in nonchromaffin cells which contaminate our cultures (less than $20 \%$ nonchromaffin cells; Wilson and Viveros, 1981), the presence of ascorbate resulted in a slight increase in cellular CA content. This finding is in contrast to that of Unsicker et al. (1980), who failed to demonstrate increased CA levels or protection from CA loss by inclusion of ascorbic acid in the medium of cultured bovine chromaffin cells. Despite the enhancement of chromaffin cell CA synthesis by ascorbic acid, reducing ascorbate levels to less than $2 \%$ of those found in freshly prepared cells did not prevent $\mathrm{CA}$ resynthesis following secretion. This lack of a requirement for ascorbic acid in CA biosynthesis is in contrast to the ability of ascorbate to serve as a source of reducing equivalents required for dopamine $\beta$-hydroxylation (Levin et al., 1960). The discovery of a high affinity uptake system in chromaffin cells for ascorbate (Daniels et al., 1982; Dean et al., 1982) and the high levels of ascorbate retained by the cells in this study also suggest a role for ascorbic acid in chromaffin cell metabolism. Studies on norepinephrine synthesis in isolated hearts from normal and scorbutic guinea pigs, however, have suggested that ascorbic acid may not be required for the conversion of dopamine to norepinephrine (Levitt et al., 1965). Hence, some alternate source of reducing equivalents for dopamine $\beta$-hydroxylation must exist, at least in the absence of an apparent adequate supply of ascorbic acid.

Insulin. Insulin has a variety of actions on many different types of cells, several of which actions may be mediated by hyperpolarization of the plasma membrane or by phosphorylation/dephosphorylation reactions (see Czech, 1977, for review). The effect of insulin on chromaffin cells in the present study was to increase protein synthesis, including synthesis of OP and PCES, which indicates that new chromaffin vesicles are synthesized. The insulin-induced increases in OP and PCES occur between 2 and 6 days of culture without further increases subsequently, suggesting that this effect of insulin is transient, as is the doubling of total cell protein that occurs (this study; Wilson and Viveros, 1981). The do- 
pamine and norepinephrine contents of the cultures, however, continue to increase throughout 12 days of culture. Insulin fails to affect the recovery of CA and OP stores following secretion, with the exception of dopamine. Insulin appears to inhibit the elevation of dopamine seen in cells stimulated in the absence of insulin, but this may result from the fact that insulin treatment itself elevates the levels of dopamine in unstimulated cells (Table IV). Our findings suggest that insulin or some insulin-like growth factor, for which insulin at high concentration may be substituting, may be important in the regulation of adrenal medullary CA and OP biosynthesis in vivo. Production and release of an insulin-like factor by chromaffin cells or other cells contaminating our cultures could account for the improvement in cellular CA retention observed upon medium "conditioning" (Wilson and Viveros, 1981).

Dexamethasone. Administration of dexamethasone to hypophysectomized rats prevents the loss of adrenal phenylethanolamine $\quad N$-methyltransferase (PNMT) which results from this surgical treatment (Wurtman and Axelrod, 1966). Glucocorticoids, including dexamethasone, also delay the decline in PNMT activity in bovine chromaffin cells under certain culture conditions (Hersey and DiStefano, 1979), although Kilpatrick et al. (1980) failed to observe this phenomenon and found that the cells retained at least $50 \%$ of their initial transferase activity over 2 weeks in culture. In cultures of rat adrenal medullary chromaffin cells, Tischler et al. (1982) found that dexamethasone enhanced the retention of epinephrine and dopamine stores when measured after 30 days in culture, but this occurred under culture conditions which allowed drastic losses of both epinephrine and norepinephrine from the cells. This effect of dexamethasone on epinephrine content may have resulted from the increased rate of tyrosine hydroxylation observed in dexamethasone-treated rat chromaffin cells. Dexamethasone produced no consistent effects on CA biosynthesis in our cultures. The possibility of glucocorticoid production by adrenal cortical cells contaminating our cultures, however, does not permit us to draw a definite conclusion about the role of these steroid hormones on CA synthesis in chromaffin cells.

Recovery of $C A$ and $O P$ stores following evoked secretion. The recovery of the OP and PCES contents of chromaffin cells stimulated to secrete large amounts of these substances suggests that new chromaffin vesicle synthesis occurs within 1 day of the stimulated depletion. Synthesis of new chromaffin vesicles occurs after adrenal medullary secretion in vivo (Viveros et al., 1969, 1971). Increases in chromaffin cell OP levels are also observed following reserpine- or tetrabenazine-induced CA depletion and are thought to represent synthesis of new chromaffin vesicles (Wilson et al., 1980, 1981, 1982). The reason for the variable extent of chromaffin cell OP recovery following stimulated secretion in the present studies is not clear but does not seem to result from altered processing of OP precursors, as indicated by the similar recovery of OPs and PCES following secretion.

Although new chromaffin vesicles appear to be synthesized within 1 day following secretion, chromaffin vesicle synthesis is not rate limiting for the recovery of
CA stores. This lag between vesicle synthesis and CA filling of the vesicles is also observed following adrenal medullary secretion in vivo (Viveros et al., 1969, 1971). The fact that norepinephrine levels in stimulated cells return to those of unstimulated controls without an overshoot suggests that the extent of new vesicle synthesis is tightly regulated. The failure to observe complete recovery of epinephrine stores may reflect limiting PNMT activity and incomplete vesicle synthesis in epinephrine-containing cells. If PNMT activity were the only limiting factor, spinephrine levels should eventually recover following secretion, but this was not observed up to 7 days poststimulation. Although OPs appear to be stored in and released from both epinephrine and norepinephrine types of chromaffin cells in culture (Wilson et al., 1982), a preferential storage of OP in epinephrinecontaining cells (Livett et al., 1982) would suggest that epinephrine recovery would be no higher than $O P$ recovery, a fact observed in the present study. The increased rate of CA biosynthesis following stimulation compared to the rate during insulin treatment, where new vesicles are probably also formed, may reflect not only increased storage sites but also increased tyrosine hydroxylase activity via phosphorylation of the enzyme (Haycock et al., 1982; Meligeni et al., 1982) as well as an increase in the number of enzyme molecules by induction of synthesis (Waymire et al., 1977; Wilson et al., 1981).

\section{References}

Chang, K. -J., and P. Cuatrecasas (1979) Multiple opiate receptors: Enkephalins and morphine bind to receptors of different specificity. J. Biol. Chem. 254: 2610-2618.

Coupland, R. E. (1965) The Natural History of the Chromaffin Cell, Longmans, London.

Czech, M. P. (1977) Molecular basis of insulin action. Annu. Rev. Biochem. 46: 359-384.

Daniels, A. J., G. Dean, O. H. Viveros, and E. J. Diliberto, Jr. (1982) Secretion of newly taken-up ascorbic acid by adrenomedullary chromaffin cells. Science 216: 737-739.

Dean, G., A. J. Daniels, S. P. Wilson, and E. J. Diliberto, Jr. (1982) Uptake of ascorhate by isolated chromaffin cells. Fed. Proc. 41: 1157.

Fenwick, E. M., P. B. Fajdiga, N. B. S. Howe, and B. G. Livett (1978) Functional and morphological characterization of isolated bovine adrenal medullary cells. J. Cell Biol. 76: 12-30.

Haycock, J. W., J. A. Meligeni, W. F. Bennett, and J. C. Waymire (1982) Phosphorylation and activation of tyrosine hydroxylase mediate the acetylcholine-induced increase in catecholamine biosynthesis in adrenal chromaffin cells. J. Biol. Chem. 257: 12641-12648.

Hersey, R. M., and V. DiStefano (1979) Control of phenylethanolamine $N$-methyltransferase by glucocorticoids in cultured bovine adrenal medullary cells. J. Pharmacol. Exp. Ther. 209: 147-152.

Kilpatrick, D. L., F. H. Ledbetter, K. A. Carson, A. G. Kirshner, R. Slepetis, and N. Kirshner (1980) Stability of bovine adrenal inedulla cells in culture. J. Neurochem. 35: 679-692.

Levin, E. Y., B. Levenberg, and S. Kaufman (1960) The enzymatic conversion of 3,4-dihydroxyphenylethylamine to norepinephrine. J. Biol. Chem. 235: 2080-2086.

Levitt, M., S. Spector, A. Sjoerdsma, S. Udenfriend (1965) Elucidation of the rate-limiting step in norepinephrine biosynthesis in the perfused guinea-pig heart. J. Pharmacol. Exp. Ther. 148: 18.

Lewis, R. V., A. S. Stern, J. Rossier, S. Stein, and S. Udenfriend 
(1979) Putative enkephalin precursors in bovine adrenal medulla. Biochem. Biophys. Res. Commun. 89: 822-829.

Livett, B. G., D. M. Dean, and G. M. Bray (1978) Growth characteristics of isolated adrenal medullary cells in culture. Soc. Neurosci. Abstr. 4: 592.

Livett, B. G., D. M. Dean, L. G. Whelan, S. Udenfriend, and J. Rossier (1981) Co-release of enkephalin and catecholamines from cultured adrenal chromaffin cells. Nature 289: 317-319.

Livett, B. G., R. Day, R. P. Elde, and P. R. C. Howe (1982) Costorage of enkephalins and adrenaline in the bovine adrenal medulla. Neuroscience 7: 1323-1332.

Lowry, O. H., N. J. Rosebrough, A. L. Farr, and R. J. Randall (1951) Protein measurement with the Folin phenol reagent. J. Biol. Chem. 193: 265-275.

Meligeni, J. A., J. W. Haycock, W. F. Bennett, and J. C. Waymire (1982) Phosphorylation and activation of tyrosine hydroxylase mediate the cAMP-induced increase in catecholamine biosynthesis in adrenal chromaffin cells. J. Biol. Chem. 257: 12632-12640.

Muller, T. H., and K. Unsicker (1981) High performance liquid chromatography with electrochemical detection as a highly efficient tool for studying catecholaminergic systems. I. Quantitation of noradrenaline, adrenaline and dopamine in cultured adrenal medullary cells. J. Neurosci. Methods $4: 39$ 52.

Naujoks, K. W., S. Korsching, H. Rohrer, and H. Thoenen (1982) Nerve growth factor-mediated induction of tyrosine hydroxylase and of neurite outgrowth in cultures of bovine adrenal chromaffin cells. Dependence on developmental stage. Dev. Biol. 92: 365-379.

Rossier, J., D. M. Dean, B. G. Livett, and S. Udenfriend (1981) Enkephalin congeners and precursors are synthesized and released by primary cultures of adrenal chromaffin cells. Life Sci. 28: 781-789.

Schneider, F. H. (1968) Observations on the release of lysosomal enzymes from the isolated bovine adrenal gland. Biochem. Pharmacol. 17: 848-851.

Schultzberg, M., J. M. Lundberg, T. Hokfelt, L. Terenius, J. Brandt, R. P. Elde, and M. Goldstein (1978) Enkephalin-like immunoreactivity in gland cells and nerve terminals of the adrenal medulla. Neuroscience 3: 1169-1186.

Tischler, A. S., R. L. Perlman, G. Nunnemacher, G. M. Morse, R. A. DeLellis, H. J. Wolfe, and B. E. Sheard (1982) Longterm effects of dexamethasone and nerve growth factor on adrenal medullary cells cultured from young rats. Cell Tissue Res. 225: 525-542.

Trifaro, J. M., and R. W. H. Lee (1980) Morphological characteristics and stimulus secretion coupling in bovine adrenal chromaffin cell cultures. Neuroscience 5: 1533-1546.

Unsicker, K., G. -H. Griesser, R. Lindmar, K. Loffelholz, and U. Wolf (1980) Establishment, characterization and fibre outgrowth of isolated bovine adrenal medullary cells in longterm cultures. Neuroscience 5: 1445-1460.

Viveros, O. H., L. Arqueros, R. J. Connett, and N. Kirshner (1969) Mechanism of secretion from the adrenal medulla. IV. The fate of the storage vesicles following insulin and reserpine administration. Mol. Pharmacol. 5: 69-82.

Viveros, O. H., L. Arqueros, and N. Kirshner (1971) Mechanism of secretion from the adrenal medulla. VII. Effect of insulin administration on the bouyant density, dopamine $\beta$-hydroxylase, and catecholamine content of adrenal storage vesicles. Mol. Pharmacol. 7: 444-454.

Viveros, O. H., E. J. Diliberto, Jr., E. Hazum, and K. -J. Chang (1979) Opiate-like materials in the adrenal medulla: Evidence for storage and secretion with catecholamines Mol. Pharmacol. 16: 1101-1108.

Viveros, O. H., M. M. Abou-Donia, C. -L. Lee, S. P. Wilson, and C. A. Nichol (1981) Control of tissue tetrahydrobiopterin levels through GTP-cyclohydrolase: A factor in the regulation of monoamine synthesis. In Function and Regulation of Monoamine Enzymes: Basic and Clinical Aspects, E. Usdin, N. Weiner, and M. Youdim, eds., pp. 241-250, MacMillian Publishers Ltd., London.

Waymire, J. C., K. G. Waymire, R. Boehme, D. Noritake, and J. Wardell (1977) Regulation of tyrosine hydroxylase by cyclic $3^{\prime}: 5^{\prime}$-adenosine monophosphate in cultured neuroblastoma and cultured dissociated bovine adrenal chromaffin cells. In Structure and Function of Monoamine Enzymes, E. Usdin, N. Weiner, and M. B. H. Youdim, eds., pp. 327-363, Marcel Dekker, New York.

Wilson, S. P., and O. H. Viveros (1981) Primary culture of adrenal medullary chromaffin cells in a chemically defined medium. Exp. Cell Res. 133: 159-169.

Wilson, S. P., K. -J. Chang, and O. H. Viveros (1980) Synthesis of enkephalins by adrenal medullary chromaffin cells: Reserpine increases incorporation of radiolabeled amino acids. Proc. Natl. Acad. Sci. U. S. A. 77: 4364-4368.

Wilson, S. P., M. M. Abou-Donia, K. -J. Chang, and O. H. Viveros (1981) Reserpine increases opiate-like peptide content and tyrosine hydroxylase activity in adrenal medullary chromaffin cells in culture. Neuroscience 6: 71-79.

Wilson, S. P., K. -J. Chang, and O. H. Viveros (1982) Proportional secretion of opioid peptides and catecholamines from adrenal chromaffin cells in culture. J. Neurosci. 2: 11501156.

Wurtman, R. J., and J. Axelrod (1966) Control of enzymatic synthesis of adrenaline in the adrenal medulla by adrenal cortical steroids. J. Biol. Chem. 241: 2301-2305.

Yang, H. -Y. T., A. M. DiGiulio, W. Fratta, J. S. Hong, E. A. Majane, and E. Costa (1980) Enkephalin in bovine adrenal gland: Multiple molecular forms of $\left[\mathrm{Met}^{5}\right]$ enkephalin immunoreactive peptides. Neuropharmacology 19: 209-215. 